Article

\title{
Temporal and Spatial Variation Trends in Water Quality Based on the WPI Index in the Shallow Lake of an Arid Area: A Case Study of Lake Ulansuhai, China
}

\author{
Qi Zhang ${ }^{1}$, Ruihong Yu ${ }^{1,2, *}$, Ye Jin ${ }^{1}$, Zhuangzhuang Zhang ${ }^{1}$, Xinyu Liu ${ }^{1}$, Hao Xue ${ }^{1}$, \\ Yanling Hao ${ }^{1,2}$ and Lixin Wang ${ }^{1,2}$ \\ 1 School of Ecology and Environment in Inner Mongolia University, Key Laboratory of River and Lake in \\ Inner Mongolia Autonomous Region, Hohhot 010021, Inner Mongolia Autonomous, China \\ 2 Key Laboratory of Ecology and Resources Use of the Mongolian Plateau of Ministry of Education, \\ Hohhot 010021, Inner Mongolia Autonomous, China \\ * Correspondence: rhyu@imu.edu.cn; Tel.: +86-471-4991729
}

Received: 7 May 2019; Accepted: 5 July 2019; Published: 9 July 2019

\begin{abstract}
Ulansuhai, the largest shallow lake of the Yellow River of China, is an important component of the Hetao region irrigation system. Many concerns have concentrated on its water quality, which affects the local water security and sustainable economic development. In this study, the water pollution index (WPI), an effective water quality evaluation method, was used to compare the pollution levels among pollution indicators and to determine the major pollution indicators. The regime shift index (RSI) approach was employed to identify the water quality trends. Cluster analysis and Daniel trend test methods were employed to analyse the inner-annual and inter-annual spatio-temporal trends of the typical water quality indicators (e.g., total nitrogen (TN), total phosphorus (TP), dissolved oxygen (DO), and chemical oxygen demand (COD)) in Lake Ulansuhai. The results show that the water quality of Ulansuhai improved from 1998 to 2017; spatial variations in the $\mathrm{WPI}_{\mathrm{TN}}, \mathrm{WPI}_{\mathrm{TP}}$, and $\mathrm{WPI}_{\mathrm{DO}}$ followed the order of inlet $>$ centre and outlet, while spatial variations in the WPI $\mathrm{COD}_{\mathrm{C}}$ showed the order of outlet $>$ inlet $>$ centre. TN was the critical pollution indicator throughout the year. In 2017, the dry season and wet season were determined using cluster analysis. The WPI ${ }_{C O D}$ was higher than the $\mathrm{WPI}_{\mathrm{TN}}, \mathrm{WPI}_{\mathrm{TP}}$, and $\mathrm{WPI}_{\mathrm{DO}}$ in the dry season, while the $\mathrm{WPI}_{\mathrm{TN}}, \mathrm{WPI}_{\mathrm{TP}}$, and $\mathrm{WPI}_{\mathrm{DO}}$ were higher than the WPI $\mathrm{COD}_{\mathrm{C}}$ in the wet season. WPI was grouped into three clusters: highly polluted regions, moderately polluted regions, and less polluted regions, However, there is a discrepancy between the three polluted regions that were divided into the dry season and the wet season. The WPI $\mathrm{COD}_{\mathrm{C}}$ was highest among all pollution indicators in 2017. Major sources of pollution that contribute to the deterioration of water quality include inner-annual or inter-annual pollution, agricultural non-point pollution, point source pollution, and internal pollution. This study provides useful information for authorities to effectively manage water quality and control water pollution.
\end{abstract}

Keywords: Lake Ulansuhai; spatio-temporal variation; water pollution index (WPI); daniel trend test; cluster analysis; regime shift

\section{Introduction}

As an important source of freshwater on earth, lakes play an irreplaceable role in maintaining the balance of ecosystems in the basin [1]. The determination of water quality is important to assess the health of a watershed and to make necessary management decisions to control current and future pollution in receiving water bodies [2]. There are numerous methods for water quality evaluation, 
such as fuzzy comprehensive evaluation [3], the grey relational method [4], multivariate statistical methods [5], the artificial neural network [6] and the comprehensive pollution index method [7]. The fuzzy comprehensive evaluation method is used for the comprehensive evaluation of water quality with high requirements and a multitude of uncertain factors. The grey relational method can determine the water quality level by comparing the results from monitoring data and surface water quality standards. The principal component analysis can be applied to water quality assessment when using various evaluation indicators. The neural network method can objectively and accurately obtain the evaluation results of the water quality standard class. The comprehensive pollution index method can determine the main pollutants and establish the correspondence between multiple water quality indicators and their corresponding standards. In contrast, the water pollution index (WPI) extends the single factor evaluation method and has several apparent advantages. These advantages include the identification of major pollutants, comparison of the pollution degree for different water quality indicators, quantitative assessment of the water quality, and comparison of the inferior to $\mathrm{V}$ water quality standard classes. Most importantly, it can show the spatio-temporal variation in lake water quality and simplify the calculation procedure [8-10].

Currently, the evaluation of water quality is mainly based on single indicators of physical, chemical, hydrological, microbiological, and biological features, etc. When analysing numerous water quality indicators, it is often difficult to explain the water quality assessment results because each indicator has a different quality class. The WPI value overcomes this problem and can explain the water quality more clearly [11] by providing a single assessment score, which can be used to compare different indicators' pollution degrees. Wang et al. used the WPI to evaluate the riverine water quality of the north bank in Dianchi Lake [12] and combined the multivariate statistical analysis, WPI, and Daniel trend test methods to evaluate the spatial and temporal variations in water quality in Fuxian Lake [13]. Liu et al. used the WPI to evaluate the water quality of a mainstream river in Shandong Province, and found that the WPI is more consistent with the riverine macroscopic governance process in the river and more concise than other water quality assessment methods [14]. Li et al. presented a fuzzy water pollution index method (FWPI) to evaluate the water quality of Sichuan Qu River and compared it with the methods of fuzzy comprehensive evaluation and grey relational analysis. They found the evaluation results of the FWPI to be more reliable [15]. Ana used the WPI to analyse the water quality of the Danube-Tisa-Danube Canal in Serbia from 2004 to 2009 and conducted a pollution assessment [16]. Jovana applied the WPI to assess the water pollution status of four hydrological stations in 1993-1996 and 2006-2009. The results showed that the significant increase in the inorganic pollution index (Fe, $\mathrm{Mn}$ ) of the Borska Reka River was mainly caused by mining, while the increase in organic pollution indicators (ammonia, E. coli, $\mathrm{BOD}_{5}$ ) in Timok River was due to the voluntary discharge of domestic sewage [17]. In Greece, the WPI has also been applied to the assessment of drinking water quality [18]. In addition, the revised WPI was utilised to quantify environmental changes in the Mersey Basin in England by combining it with historical and geographic methods [19]. Currently, the WPI is mostly used for the evaluation of water quality in domestic humid and semi-humid areas. However, there have been fewer applications of this method in arid and semi-arid regions.

Lake Ulansuhai, the largest shallow lake in the Yellow River Basin of China, has an important ecological status and huge socioeconomic effects. Its water quality directly affects the water security of the residents in the lower Yellow River basin [20]. However, with the increase in intensive human activities, the lake is suffering from many problems, including increases its nutrient concentration and organic pollution, as well as eutrophication [21]. The nutrient input exceeds the water environment capacity, resulting in algal blooms under appropriate weather conditions. Abloom-prone area covers approximately $10 \mathrm{~km}^{2}$ in Xidatan area of Lake Ulansuhai [22]. So far, many studies have been conducted on the distribution characteristics of nutrient status during the frozen period and non-frozen period [23]. Moreover, some researchers have carried out comprehensive evaluation and analysis ofthe water quality of the Lake Ulansuhai through various methods, such as the fuzzy comprehensive evaluation method [24] and the grey model evaluation method [25]. The WPI is a useful tool for evaluating the 
water quality, as it can integrate a series of water quality data into a single number with a simple formula and assess results based on different quality indicators. It can also completely eliminate the influence of variable dimension and reflect the pollution degree of surface water that has been applied extensively worldwide.

The aims of this study are as follows: (1) Evaluate the water quality of spatio-temporal variation based on the WPI on the inter-annual scale (1998-2017) and reveal the major pollution indicators; (2) combine WPI, cluster analysis method, and Daniel trend analysis to analyse the inner-annual (2017) spatio-temporal variation trends of the main pollution indicators; (3) investigate the main reasons for the inter and inner annual variation in the WPI of water quality indicators; and (4) provide a reference and rational suggestions for the improvement and effective management of lake water quality.

\section{Materials and Methods}

\subsection{Study Area}

Lake Ulansuhai $\left(40^{\circ} 36^{\prime}-41^{\circ} 03^{\prime} \mathrm{N}, 108^{\circ} 43^{\prime}-108^{\circ} 57^{\prime} \mathrm{E}\right)$, located in northeast Urad Qianqi, Bayannur city, Inner Mongolia, China, is a typical shallow lake in the semiarid regions and is the largest freshwater lake in the Yellow River Basin [26]. The lake area is $293 \mathrm{~km}^{2}$ and its depth ranges from 0.5 to $2.5 \mathrm{~m}$. The average annual precipitation is approximately $200 \mathrm{~mm}$ and the potential evaporation is $2300 \mathrm{~mm}$ [27]. Various pollutants from agricultural practices, industrial production, and domestic discharge to Lake Ulansuhai, impact the aquatic environment and lead to the degradation of ecosystem function as well as intensified and intensified eutrophication [22]. Currently, large-scale outbreaks of Huangtai algae have seriously threatened the habitat of animals and plants in Ulansuhai Lake and destroyed fishery resources. The ecological environment of the lake is extremely fragile. Lake Ulansuhai has been suffering from increasing eutrophication as a result of non-point pollution from Hetao Irrigation District. Lake Ulansuhai is significant for maintaining the ecological and environmental health and water function in the Yellow River Basin.

\subsection{Data Collection and Measurement}

Water quality data from 1998 to 2017 in the inlet, centre, and outlet of Lake Ulansuhai were measured by the Inner Mongolia Environmental Station in April, July, and October, respectively. Thirteen sampling sites were selected to collect water in January, April, June, July, August, and October of 2017 based on a $2 \times 2 \mathrm{~km}$ plum-shape (Figure 1), and indicators such as total nitrogen (TN), total phosphorus (TP), dissolved oxygen (DO), and chemical oxygen demand (COD) were measured. The measurement methods are listed in Table 1.

Table 1. Water quality indicators and the corresponding measurement methods.

\begin{tabular}{|c|c|c|c|}
\hline Indicators & Abbreviations & Units & Measurement Methods \\
\hline Total nitrogen & $\mathrm{TN}$ & $\mathrm{mg} / \mathrm{L}$ & $\begin{array}{l}\text { Potassium persulfate UV } \\
\text { spectrophotometry }\end{array}$ \\
\hline Total phosphorus & $\mathrm{TP}$ & $\mathrm{mg} / \mathrm{L}$ & $\begin{array}{l}\text { Molybdenum antimony anti } \\
\text { spectrophotometry }\end{array}$ \\
\hline Dissolved oxygen & $\mathrm{DO}$ & $\mathrm{mg} / \mathrm{L}$ & $\begin{array}{c}\text { German-made WTW series } \\
\text { multi } 3420 \text { portable } \\
\text { multi-parameter metre }\end{array}$ \\
\hline $\begin{array}{c}\text { Chemical oxygen } \\
\text { demand }\end{array}$ & $\mathrm{COD}_{\mathrm{cr}}$ & $\mathrm{mg} / \mathrm{L}$ & Dichromate titration \\
\hline
\end{tabular}



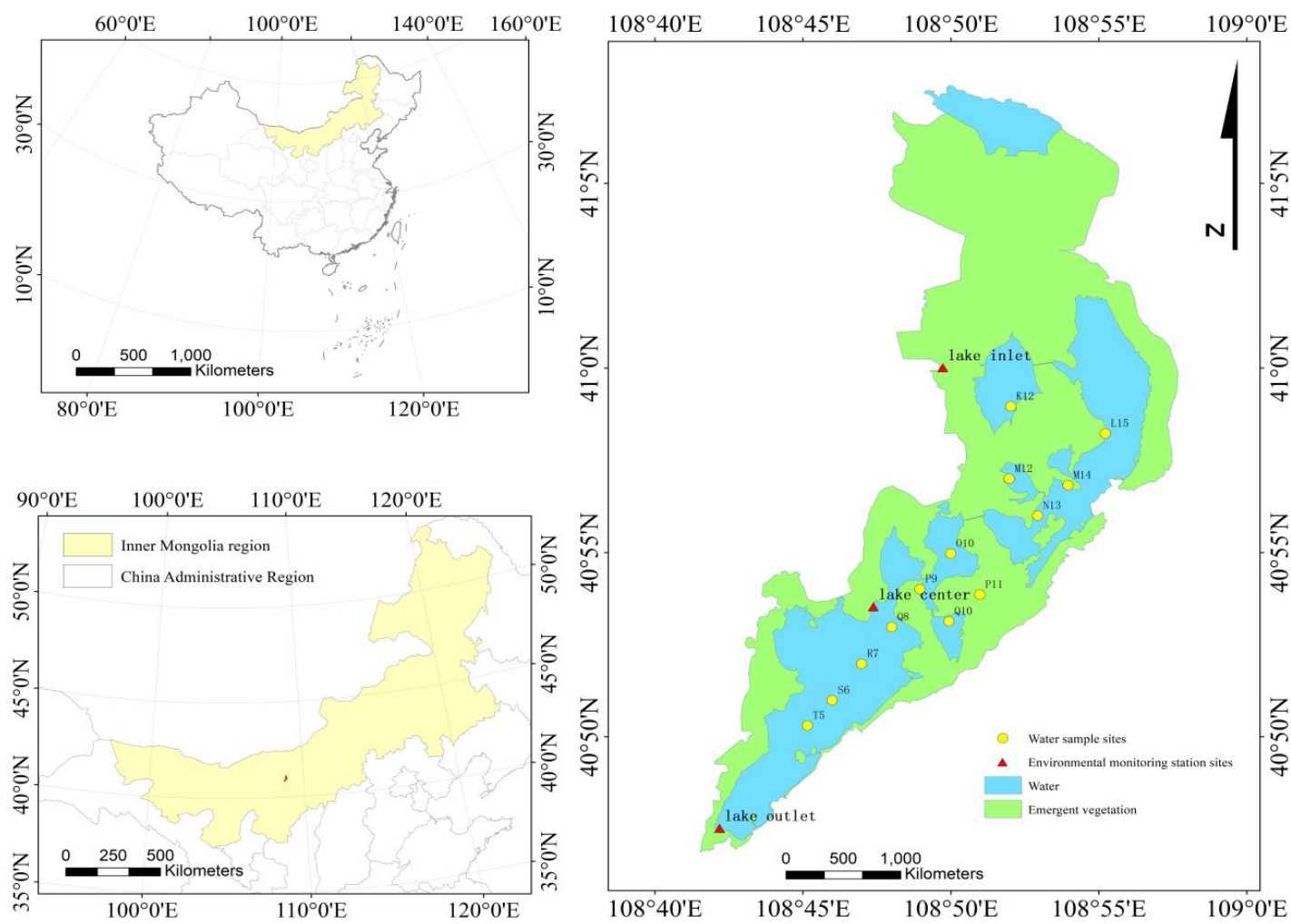

Figure 1. Geographical location of the sampling sites in Lake Ulansuhai.

\subsection{Data Analysis Methods}

\subsubsection{Selection of Water Quality Indicators}

Four indicators, including TN, TP, DO, and COD, were selected as the typical indicators to express the eutrophication level of Lake Ulansuhai, of which TN and TP are significant indices of eutrophication, DO is an indicator of water ecosystem health reflecting the water self-purification capacity [25], and COD is primarily used to characterize the organic pollutants in the water.

\subsubsection{Water Pollution Index (WPI)}

The calculation of the WPI was based on China's surface water environmental quality standards (GB3838-2002) [28]. This method can compare the pollution level between different indicators and reveal the major pollution indicators [13]. The $\mathrm{WPI}_{\mathrm{TN}}, \mathrm{WPI}_{\mathrm{TP}}, \mathrm{WPI} \mathrm{I}_{\mathrm{DO}}$, and $\mathrm{WPI}_{\mathrm{COD}}$ are expressed as the corresponding WPI values of TN, TP, DO, and COD. The water quality standard classes and their WPI values are shown in Table 2.

Table 2. China's national water quality standards for total nitrogen (TN), total phosphorus (TP), chemical oxygen demand (COD), and dissolved oxygen (DO) and their corresponding water pollution index (WPI) values.

\begin{tabular}{cccccc}
\hline & First Level & Second Level & Third Level & Fifth Level & $\begin{array}{c}\text { Inferior to } \\
\text { Fifth Level }\end{array}$ \\
\hline $\mathrm{TP}(\mathrm{mg} / \mathrm{L})$ & 0.01 & 0.025 & 0.05 & 0.2 & $>0.2$ \\
$\mathrm{TN}(\mathrm{mg} / \mathrm{L})$ & 0.2 & 0.5 & 1 & 2 & $>2.0$ \\
$\mathrm{DO}(\mathrm{mg} / \mathrm{L})$ & 7.5 & 6 & 5 & 2 & $<2.0$ \\
$\mathrm{COD}(\mathrm{mg} / \mathrm{L})$ & 15 & 15 & 20 & 40 & $>40$ \\
WPI & 20 & $20<\mathrm{WPI} \leq 40$ & $40<\mathrm{WPI} \leq 60$ & $80<\mathrm{WPI} \leq 100$ & $>100$ \\
\hline
\end{tabular}


When the concentrations of TN, TP, and COD range from surface water quality standards Class I to Class V (GB3838-2002), the equation is as follows:

$$
\mathrm{WPI}(\mathrm{i})=\mathrm{WPI}_{\mathrm{l}}(\mathrm{i})+\frac{\mathrm{WPI}_{\mathrm{h}}(\mathrm{i})-\mathrm{WPI}_{\mathrm{l}}(\mathrm{i})}{\mathrm{C}_{\mathrm{h}}(\mathrm{i})-\mathrm{C}_{\mathrm{l}}(\mathrm{i})} \times\left(\mathrm{C}(\mathrm{i})-\mathrm{C}_{\mathrm{l}}(\mathrm{i})\right)
$$

When the concentration of DO is above $7.5 \mathrm{mg} / \mathrm{L}$, the WPI $\mathrm{DO}_{\text {is }} 20$. When $2 \leq \mathrm{DO}<7.5 \mathrm{mg} / \mathrm{L}$, the WPI $I_{D O}$ is defined as:

$$
\mathrm{WPI}(\mathrm{i})=\mathrm{WPI}_{1}(\mathrm{i})+\frac{\mathrm{WPI}_{\mathrm{h}}(\mathrm{i})-\mathrm{WPI}_{1}(\mathrm{i})}{\mathrm{C}_{\mathrm{h}}(\mathrm{i})-\mathrm{C}_{\mathrm{l}}(\mathrm{i})} \times\left(\mathrm{C}_{1}(\mathrm{i})-\mathrm{C}(\mathrm{i})\right)
$$

When the concentrations of water quality indicators are higher than class V(GB3838-2002), the following Equation is used:

$$
\mathrm{WPI}(\mathrm{i})=100+\frac{\mathrm{C}(\mathrm{i})-\mathrm{C}_{5}(\mathrm{i})}{\mathrm{C}_{5}(\mathrm{i})} \times 40
$$

In Equations (1)-(3), C (i) is the concentration of indicator $\mathrm{i}, \mathrm{C}_{\mathrm{h}}(\mathrm{i})$ is the maximum concentration of indicator $i, C_{1}(i)$ is the minimum concentration of indicator $i, C_{5}(i)$ is the upper limit of Class $V$ of indicator $i$, WPI $(i)$ is the WPI value of indicator $i, W^{2} I_{h}(i)$ is the maximum WPI value of indicator $i$, and $\mathrm{WPI}_{1}(\mathrm{i})$ is the minimum WPI value of indicator $\mathrm{i}$.

\subsubsection{Daniel Trend Test}

The Daniel trend test is a non-parametric test which can provide a quantitative evaluation of temporal and spatial variation trends. This method adopts Spearman rank correlation coefficient $\left(\mathrm{W}_{\mathrm{p}}\right)$ to inspect the significance of changes in trends. The Daniel rank correlation coefficient can be calculated using Equation (4):

$$
\begin{gathered}
\mathrm{R}_{\mathrm{s}}=1-\left[6 \sum_{\mathrm{i}=1}^{\mathrm{N}} \mathrm{D}_{\mathrm{i}}^{2}\right] /\left(\mathrm{N}^{3}-\mathrm{N}\right) \\
\mathrm{D}_{\mathrm{i}}=\mathrm{X}_{\mathrm{i}}-\mathrm{Y}_{\mathrm{i}}
\end{gathered}
$$

where $R_{\mathrm{S}}$ is the rank correlation coefficient, $D_{\mathrm{i}}$ is the difference between $X_{\mathrm{i}}$ and $Y_{\mathrm{i}}, \mathrm{X}_{\mathrm{i}}$ is the sequence number of the raw concentration value of a water sample from 1 to $N, Y_{i}$ is the order number arranged by the time sequence number or the spatial arrangement of the serial number, and $\mathrm{N}$ is the number of sampling periods or the number of sampling sites. Comparing $\left|R_{s}\right|$ to the Spearman rank correlation $W_{p}$, when $\left|R_{s}\right|>W_{p}$, the trend is significant. If $R_{s}>0$, the trend is aggravated and increased. If $R_{s}<0$, the trend is the opposite $[29,30]$. When $\left|R_{s}\right| \leq W_{p}$, the trend is not significant, indicating that water quality changes stably throughout the evaluation period.

\subsubsection{Regime Shift Index (RSI)}

Based on the Students t-test using MATLAB software (2015b, MathWorks, Natick, MA, USA), for one-time series $\{x(t), t=1,2, \ldots, M\}$ from 1998 to 2017, the regime shift index (RSI) is expressed as follows:

$$
\begin{gathered}
\text { RSI }=\mathrm{T}_{- \text {test }}\left(\mathrm{t}_{0}\right)=\frac{\overline{\mathrm{x}_{2}}-\overline{\mathrm{x}_{1}}}{\sqrt{\frac{1}{\mathrm{~N}_{\mathrm{t} t=\mathrm{t}_{0}+1}}\left[\mathrm{t} \mathrm{t}_{0}+\mathrm{N}(\mathrm{t})-\overline{\mathrm{x}_{2}}\right]^{2}+\frac{1}{N} \sum_{\mathrm{t}=\mathrm{t}_{0}-\mathrm{N}}^{\mathrm{t}_{0}-1}\left[\mathrm{x}(\mathrm{t})-\overline{\mathrm{x}_{1}}\right]^{2}}} \\
\overline{x_{1}}=\frac{1}{N} \sum_{t=t_{0}-N}^{t_{0}-1} x(t) \text { and } \overline{x_{2}}=\frac{1}{N} \sum_{t=t_{0}+1}^{t_{0}+N} x(t)
\end{gathered}
$$

where $\mathrm{N}=2$ and, $\mathrm{M}=20$, the degrees of freedom for the test are $2 \mathrm{~N}-2$, and $\mathrm{t}_{0}$ is the central time from $\mathrm{N}+1$ to $\mathrm{M}-\mathrm{N} \cdot \overline{x_{1}}$ is the average of $\mathrm{N}$ time series before $\mathrm{t}_{0}$, and $\overline{x_{2}}$ is the average of $\mathrm{N}$ time series after $t_{0}$. The running RSI is correlated with the two years before and after the central year, and the Student's $\mathrm{t}$-test confidence level is used to identify the significance of the changes [31-33]. 


\section{Results}

\subsection{Inter-Annual Spatio-Temporal Variation in WPI Values during 1998-2017}

\subsubsection{Temporal Variations in $\mathrm{WPI}_{\mathrm{TN}}, \mathrm{WPI}_{\mathrm{TP}}, \mathrm{WPI}_{\mathrm{DO}}$, and $\mathrm{WPI}_{\mathrm{COD}}$}

The temporal variations in the $\mathrm{WPI}_{\mathrm{TN}}, \mathrm{WPI}_{\mathrm{TP}}, \mathrm{WPI}_{\mathrm{DO}}$, and $\mathrm{WPI}_{\mathrm{COD}}$ are shown in Figure $2 \mathrm{a}-\mathrm{d}$. Higher WPI values of $\mathrm{WPI}_{\mathrm{TN}}, \mathrm{WPI}_{\mathrm{TP}}$, and $\mathrm{WPI}_{\mathrm{COD}}$ indicate heavier water pollution, while the DO concentration trend is opposite to its WPI value: the higher the DO concentration, the lower the WPI $I_{D O}$ value and the better the water quality.
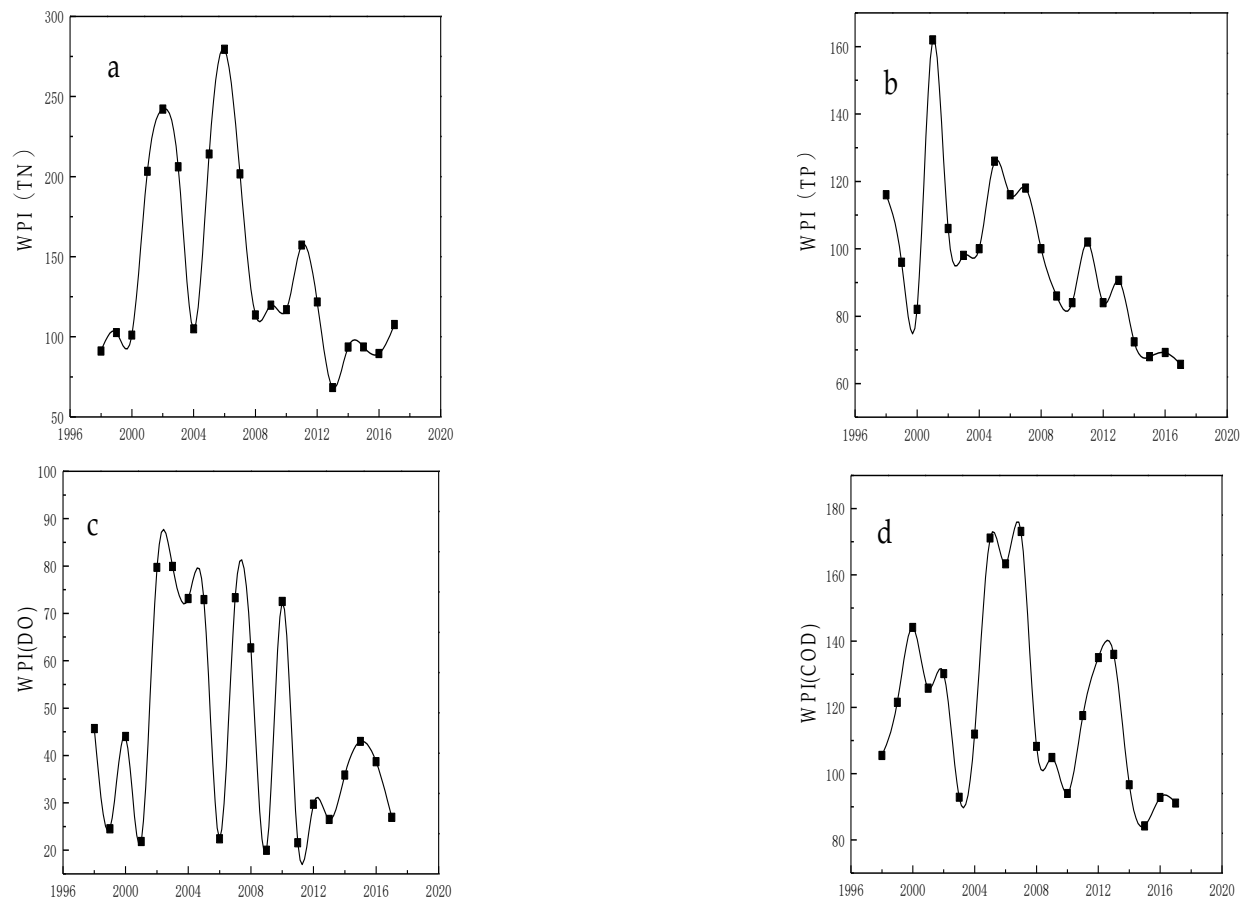

Figure 2. Inter-annual variation in the trends of the $\mathrm{WPI}_{\mathrm{TN}}, \mathrm{WPI}_{\mathrm{TP}}, \mathrm{WPI}_{\mathrm{DO}}$, and $\mathrm{WPI}_{\mathrm{COD}}$ : (a) $\mathrm{WPI}_{\mathrm{TN}}$; (b) $\mathrm{WPI}_{\mathrm{TP}}$; (c) $\mathrm{WPI}_{\mathrm{DO}}$; (d) WPI $\mathrm{COD}$.

The $\mathrm{WPI}_{\mathrm{TN}}$ in the Lake Ulansuhai ranged from 68 in 1998 to 279 in 2017. The multi-annual average $\mathrm{WPI}_{\mathrm{TN}}$ was 141.4, which indicates serious pollution and a water quality standard class inferior to Class $\mathrm{V}$. The $\mathrm{WPI}_{\mathrm{TN}}$ was approximately 100 and remained stable from 1998 to 2000. It rose sharply to 242 in 2002, decreased to 105 in 2004, and increased again to 279 in 2006. In 2008-2017, it was relatively stable, with only a small fluctuation in 2011 and 2013, respectively.

The $\mathrm{WPI}_{\mathrm{TP}}$ presented a decreasing trend with fluctuations that varied from 65 in 1998 to 162 in 2017. The multi-annual average $\mathrm{WPI}_{\mathrm{TP}}$ was 97 . In 2001, the $\mathrm{WPI}_{\mathrm{TP}}$ appeared abnormal, showing a maximum of 162 .

The temporal variation in the $\mathrm{WPI}_{\mathrm{DO}}$ can be divided into three stages: 1998-2001, 2002-2010, and 2011-2017. From 1998 to 2001, the WPI ${ }_{D O}$ fluctuated by approximately 35. It reached 80 quickly in 2002 and kept a relatively high value of 70 in 2002-2010, except in 2006 and 2009. In 2006 and 2009, the $\mathrm{WPI}_{\mathrm{DO}}$ was approximately 23. In 2011 and 2017, the WPI $\mathrm{DO}_{\mathrm{DO}}$ showed a decreasing trend and fluctuated by approximately 30 . In the past 20 years, the WPI $\mathrm{DO}_{\mathrm{DO}}$ has varied from 20 to 80 with an average of 45.7, much lower than that of the $\mathrm{WPI}_{\mathrm{TN}}, \mathrm{WPI}_{\mathrm{TP}}$, and $\mathrm{WPI} \mathrm{COD}_{\mathrm{CO}}$. It was not the main water pollution indicator of Lake Ulansuhai.

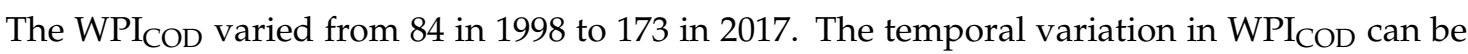
described using three stages. During the first stage (1998-2003), the WPI ${ }_{C O D}$ reached 144 in 2000 and decreased to 92.8 in 2003. During the second stage (2003-2010), the $\mathrm{WPI}_{\mathrm{COD}}$ reached its maximum in 
2007, was above 160 in 2005-2007, and then decreased to 94 in 2010. During the third stage (2011-2017), the water quality deteriorated again in 2012 and 2013 with a $\mathrm{WPI}_{\mathrm{COD}}$ value of 135 . The $\mathrm{WPI}_{\mathrm{COD}}$ decreased to 84 in 2015. Compared to the first and second stages, the water quality appears to have improved in the most recent four years.

The RSI method, based on the running Student's t-test, provided the ability to establish a significant confidence level for the differences between years and allowed an assessment of the most apparent regime shift data. Figure 3 shows the results of the regime shift analysis across the years.
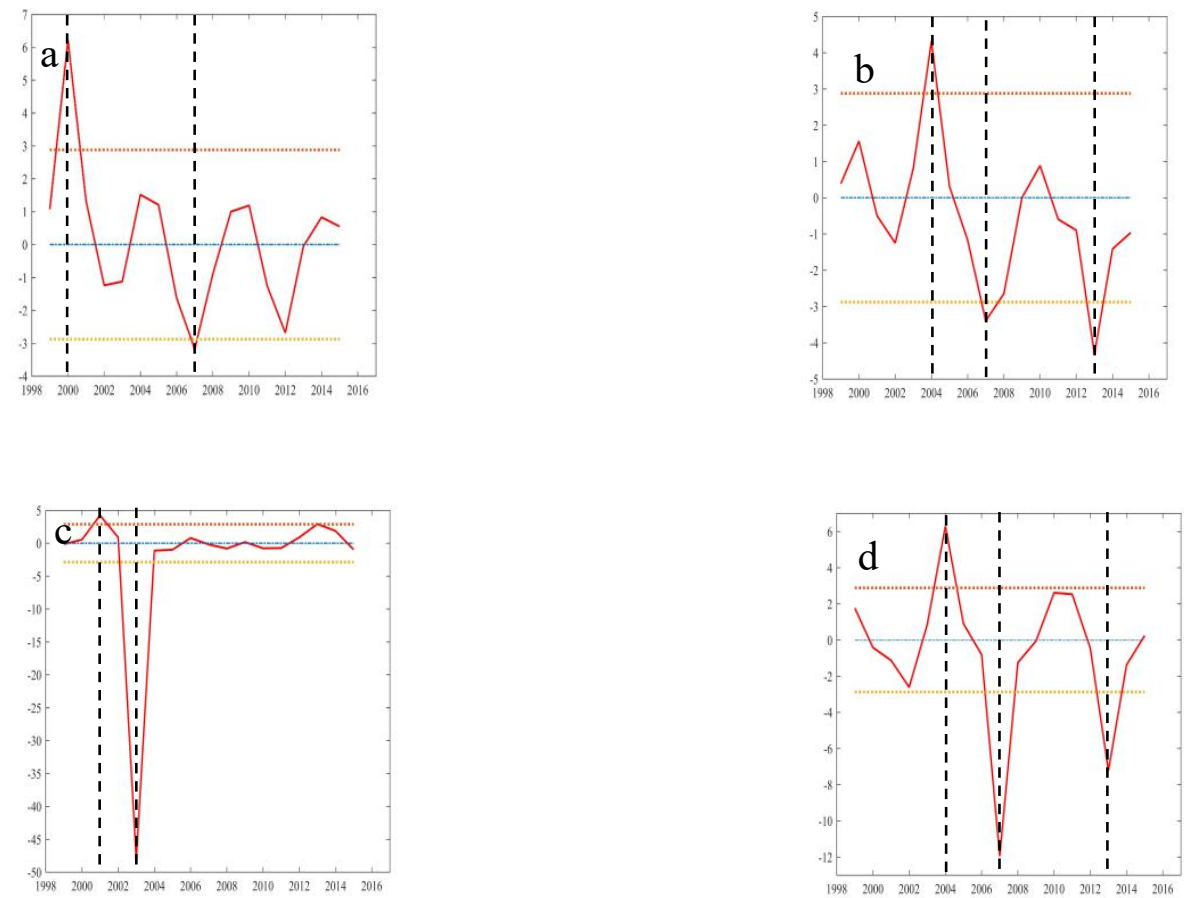

Figure 3. Regime Shift Index (RSI) based on the Student's t-test from 1998 to 2017: (a) WPI $\mathrm{TN}_{\mathrm{TN}}$ (b) $\mathrm{WPI}_{\mathrm{TP}} ;$ (c) $\mathrm{WPI}_{\mathrm{DO}} ;(\mathbf{d}) \mathrm{WPI}_{\mathrm{COD}}$.

Regime shifts in the of $\mathrm{WPI}_{\mathrm{TN}}$ occurred in 2000 and 2007 (Figure 3a) and the $\mathrm{WPI}_{\mathrm{DO}}$ showed statistically significant changes in 2001 and 2003 (Figure 3c). Furthermore, the results of the WPI $\mathrm{TP}_{\mathrm{TP}}$ and WPI $_{C O D}$ show that the regime shift years were 2004, 2007, and 2013 (Figure 3b,d).

The horizontal dashed line indicates the significance test at the $99 \%$ confidence level, and the vertical dashed line indicates the extreme point of the significant region.

\subsubsection{Spatial Variation in the WPI}

The spatial variations in the $\mathrm{WPI}_{\mathrm{TN}}, \mathrm{WPI}_{\mathrm{TP}}, \mathrm{WPI}_{\mathrm{DO}}$, and $\mathrm{WPI} \mathrm{COD}_{\mathrm{C}}$ in the inlet, centre, and outlet regions are shown in Figure 4a-d, and Figure 4e shows the box and whisker plots of spatial variation in Ulansuhai. According to the average value of WPI in the past 20 years, the spatial variation in the $\mathrm{WPI}_{\mathrm{TN}}, \mathrm{WPI}_{\mathrm{TP}}$, and $\mathrm{WPI}_{\mathrm{DO}}$ followed the order of inlet $>$ outlet and centre, and the spatial variation in the WPI $\mathrm{COD}_{\mathrm{C}}$ generally followed the order of outlet $>$ inlet $>$ centre. The water quality was better in the lake centre. 

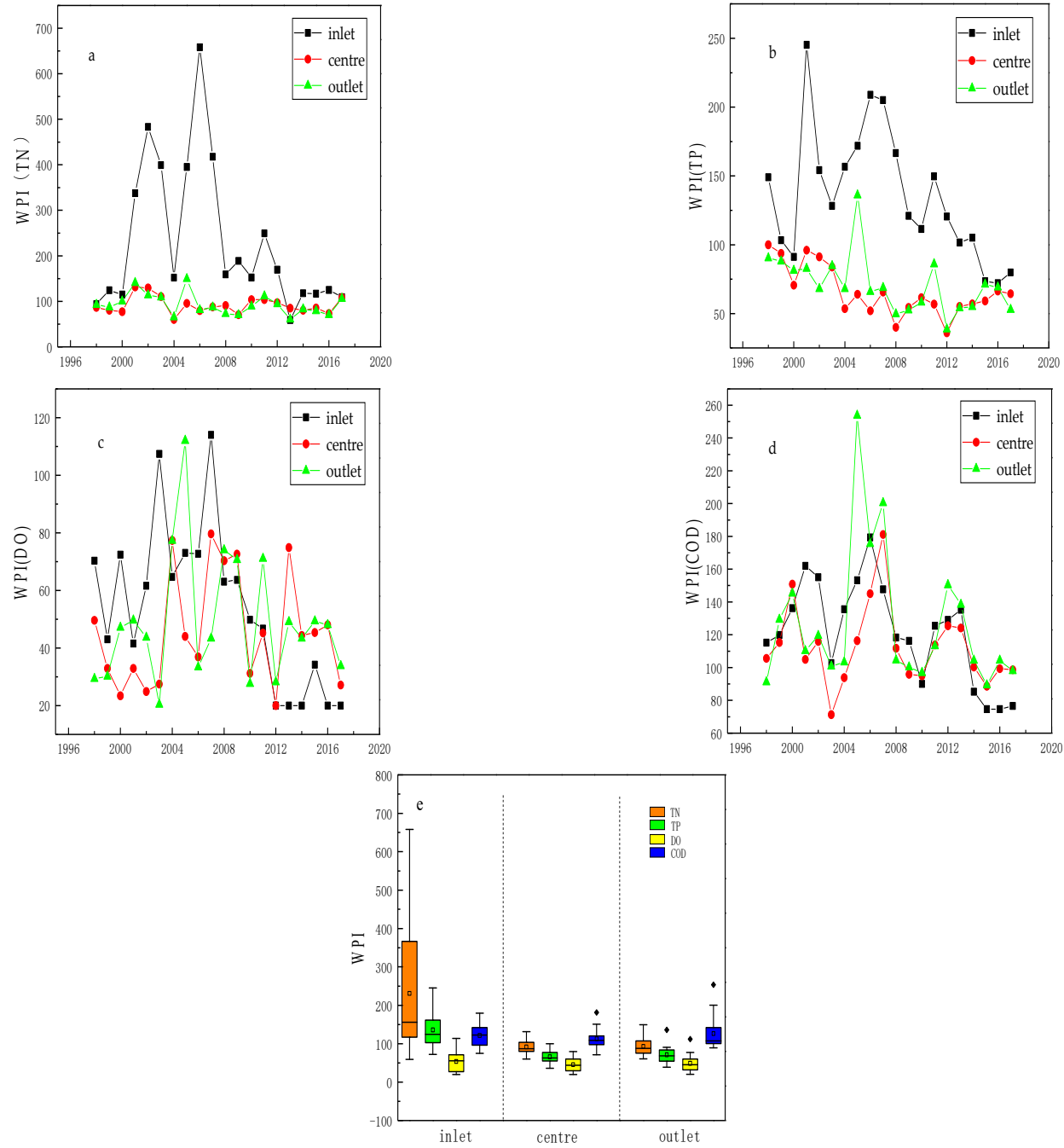

Figure 4. Concentrations of relevant water quality indicators and spatial variation in the WPI: (a) WPI $\mathrm{TN}$; (b) $\mathrm{WPI}_{\mathrm{TP}}$; (c) $\mathrm{WPI}_{\mathrm{DO}}$; (d) $\mathrm{WPI}_{\mathrm{COD}}$; (e) the box and whisker plots of spatial variation in Ulansuhai.

The $\mathrm{WPI}_{\mathrm{TN}}$ and $\mathrm{WPI}_{\mathrm{TP}}$ in the inlet were much higher than those in the lake centre and outlet in 1998-2017. The WPI $\mathrm{DO}_{\mathrm{D}}$ was higher in the lake inlet than that in the centre and outlet between 1998 and 2003. The WPI $I_{D O}$ in the lake inlet was lower than in the outlet and centre in 2012-2017. The WPI had no apparent variation in 2004-2011, and the water quality had improved. Spatial variation in the WPI ${ }_{C O D}$ was not evident in 1998-2017, of which the highest value appeared in 2005-2007 in the inlet of the lake.

In general, the WPI $\mathrm{TN}_{\mathrm{TN}}$ had the highest value followed by WPI $\mathrm{COD}_{\mathrm{C}}, \mathrm{WPI}_{\mathrm{TP}}$, and $\mathrm{WPI}_{\mathrm{DO}}$. TN was the most polluted water indicator over the past 20 years. Based on the average value of the $\mathrm{WPI}_{\mathrm{TN}}$ of 141, the water quality of the Lake Ulansuhai was inferior to water quality standard class V in 1998-2017.

\subsection{Spatio-Temporal Variation in the WPI in 2017}

The $\mathrm{WPI}_{\mathrm{TN}}, \mathrm{WPI}_{\mathrm{TP}}, \mathrm{WPI}_{\mathrm{DO}}$, and WPI $\mathrm{COD}_{\mathrm{CO}}$ were measured in January, April, June, July, August, and October. Cluster analysis was applied to analyse the spatial similarities of the 13 sampling sites in Lake Ulansuhai. 


\subsubsection{Temporal Variation in the $\mathrm{WPI}_{\mathrm{TN}}, \mathrm{WPI}_{\mathrm{TP}}, \mathrm{WPI}_{\mathrm{DO}}$, and $\mathrm{WPI} \mathrm{I}_{\mathrm{COD}}$}

Six sampling months were grouped into two clusters by hierarchical cluster analysis. The dry season included January and April, and the wet season included June, July, August, and October (see Figure 5). Figure 6 shows the temporal variations in the $\mathrm{WPI}_{\mathrm{TN}}, \mathrm{WPI}_{\mathrm{TP}}, \mathrm{WPI}_{\mathrm{DO}}$, and $\mathrm{WPI}_{\mathrm{COD}}$ in the dry season and in the wet season.

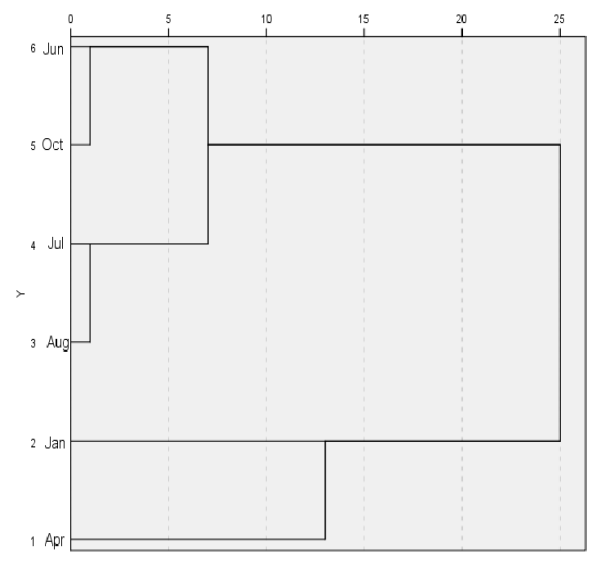

Figure 5. Cluster analysis of temporal variation in the six sampling months.

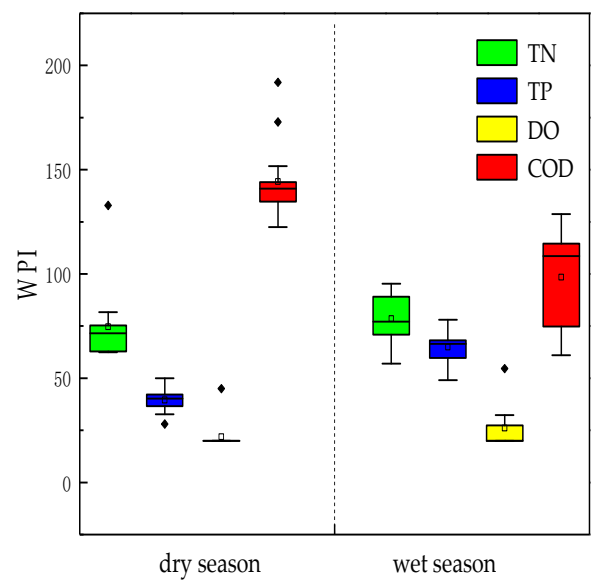

Figure 6. Box and whisker plots of temporal variation in the $\mathrm{WPI}_{\mathrm{TN}}, \mathrm{WPI}_{\mathrm{TP}}, \mathrm{WPI}_{\mathrm{DO}}$, and $\mathrm{WPI}_{\mathrm{COD}}$.

During both the dry season and wet season, the WPI ${ }_{\mathrm{COD}}$ was always higher than the $\mathrm{WPI}_{\mathrm{TN}}$, $\mathrm{WPI}_{\mathrm{TP}}$, and $\mathrm{WPI}_{\mathrm{DO}}$, and it was the major pollution indicator. The WPI $\mathrm{COD}$ was higher in the dry season, with an average value of 135 , than in the wet season. However, the average values of the $\mathrm{WPI}_{\mathrm{TN}}, \mathrm{WPI}_{\mathrm{TP}}$, and $\mathrm{WPI}_{\mathrm{DO}}$ were higher in the wet season than those in the dry season.

The monthly variations in the $\mathrm{WPI}_{\mathrm{TN}}, \mathrm{WPI}_{\mathrm{TP}}, \mathrm{WPI}_{\mathrm{DO}}$, and $\mathrm{WPI}_{\mathrm{COD}}$ are illustrated in Figure 7. The $\mathrm{WPI}_{\mathrm{TN}}, \mathrm{WPI}_{\mathrm{TP}}$, and $\mathrm{WPI}_{\mathrm{DO}}$ were higher in the wet season than in the dry season. The $\mathrm{WPI}_{\mathrm{COD}}$ was higher in the dry season than in the wet season. COD was the major pollution indicator and its WPI value was higher than $\mathrm{WPI}_{\mathrm{TN}}, \mathrm{WPI}_{\mathrm{TP}}$, and $\mathrm{WPI}_{\mathrm{DO}}$ values in both the dry and wet seasons. $\mathrm{DO}$ had the lowest WPI value.

The Daniel trend test was performed for the 13 sampling sites (see Table 3), aiming to examine the significance of the temporal variation trends in the WPI $\mathrm{TN}_{\mathrm{T}}, \mathrm{WPI} \mathrm{I}_{\mathrm{TP}}, \mathrm{WPI}_{\mathrm{DO}}$, and WPI $\mathrm{COD}_{\mathrm{C}}$ in Lake Ulansuhai. When an Rs value is greater than the Wp value, it is considered to have a significant trend; conversely, when an Rs value is less than the $\mathrm{Wp}$ value, the trend is not considered significant. Overall, the temporal variations trends in the $\mathrm{WPI}_{\mathrm{TN}}, \mathrm{WPI}_{\mathrm{TP}}, \mathrm{WPI}_{\mathrm{DO}}$, and $\mathrm{WPI} \mathrm{I}_{\mathrm{COD}}$ were relatively stable. 


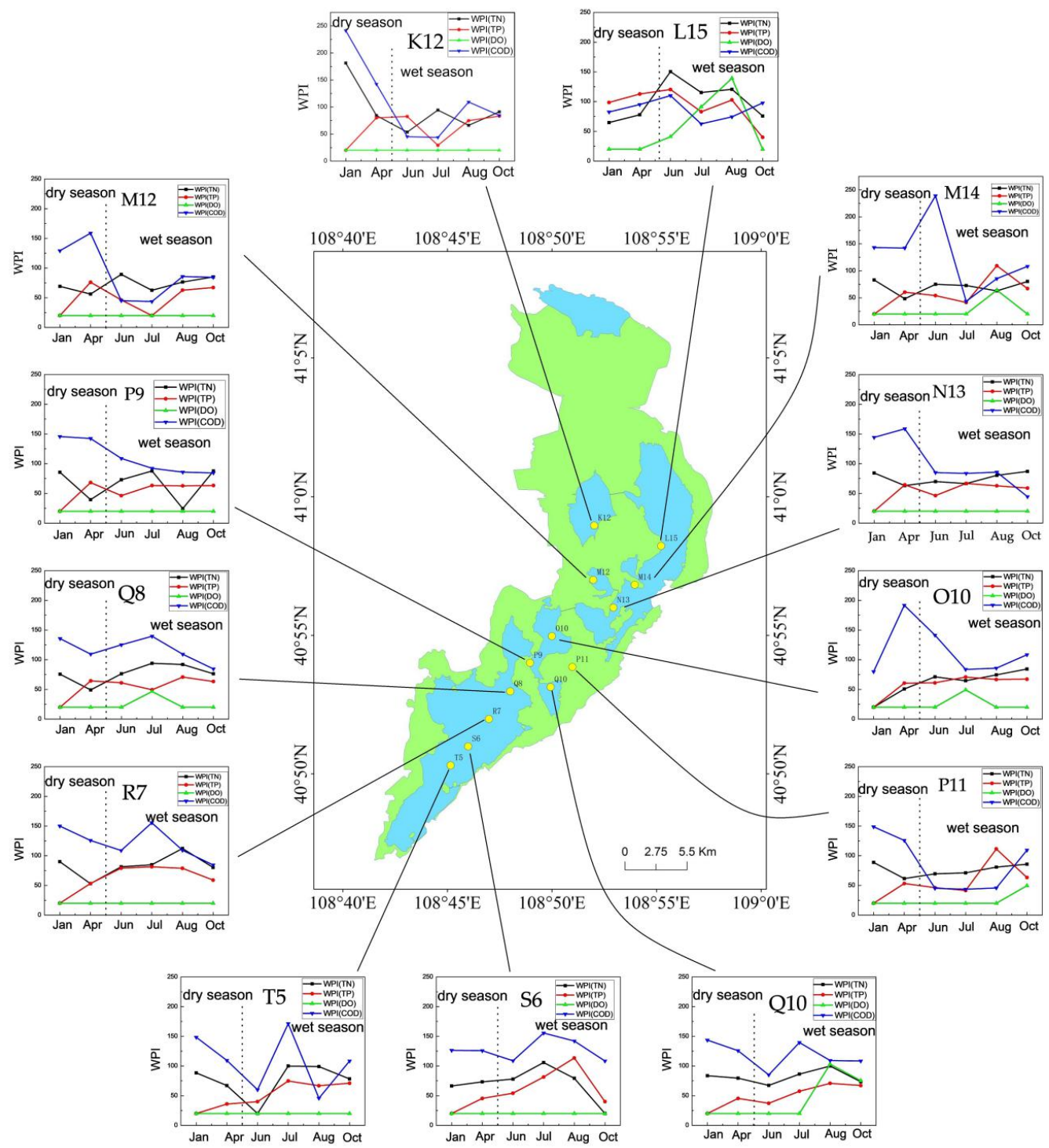

Figure 7. Temporal variation in the WPI at each sampling sites in 2017.

Table 3. Temporal variation trends calculated by the Daniel trend test method at the 13 sampling sites.

\begin{tabular}{ccccccc}
\hline Sampling Site & $\mathbf{N}$ & $\mathbf{W}^{\mathbf{a}}$ & Rs $\mathbf{( T N )}$ & Rs $\mathbf{( T P )}$ & $\begin{array}{c}\text { Rs } \\
\text { (COD }_{\mathbf{c r}} \text { ) }\end{array}$ & Rs (DO) \\
\hline K12 & 6 & 0.829 & -0.257 & 0.543 & -0.542 & 0.772 \\
L15 & 6 & 0.829 & 0.429 & 0.714 & -0.142 & -0.086 \\
M12 & 6 & 0.829 & 0.429 & 0.372 & -0.486 & 0.029 \\
M14 & 6 & 0.829 & -0.085 & 0.714 & -0.6 & 0.658 \\
N13 & 6 & 0.829 & 0.372 & 0.314 & -0.771 & 0.142 \\
O10 & 6 & 0.829 & 0.086 & 0.829 & -0.714 & 0.6 \\
P11 & 6 & 0.829 & 0.143 & 0.714 & -0.486 & 0.543 \\
P9 & 6 & 0.829 & 0.029 & 0.257 & -1 & 0.658 \\
Q10 & 6 & 0.829 & 0.086 & 0.885 & -0.542 & 0.772 \\
Q8 & 6 & 0.829 & 0.543 & 0.314 & -0.771 & 0.714 \\
R7 & 6 & 0.829 & 0.029 & 0.6 & -0.714 & 0.086 \\
S6 & 6 & 0.829 & 0.829 & 0.829 & -0.542 & 0.658 \\
T5 & 6 & 0.829 & 0.143 & 0.829 & -0.771 & 0.2 \\
\hline
\end{tabular}

( ${ }^{a} \mathrm{Rs}$ is the significance level of the unilateral tests where $<0.05$ indicates significance; when $\mathrm{N}=6, \mathrm{Wp}=0.829$ ). 


\subsubsection{Spatial Variation Trend Analysis}

The 13 sampling sites were clustered by the hierarchical cluster analysis method to analyse the spatial trend of the WPI in the dry season and wet season, respectively. The sampling sites were divided into three categories in the dry season (see Figure 8), and the box and whisker plots of spatial variation in the dry season are shown in Figure 9. Category I, including the only K12 located in the lake inlet, was defined as the highly polluted regions. Category II, defined as the moderately polluted regions, contained M12, P9, M14, N13, L15, and O10. Category III, defined as the less polluted regions, included P11, R7, Q10, T5, Q8, and S6. Category III was concentrated in the southwestern region of Lake Ulansuhai and the water quality was better in the dry season.

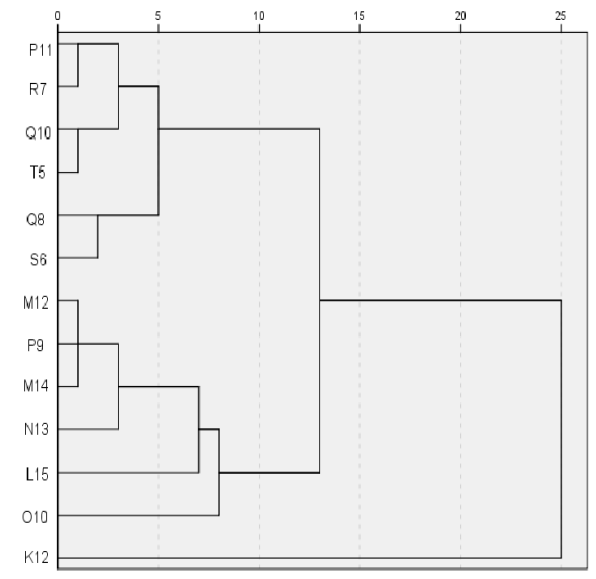

Figure 8. Cluster analysis of sampling sites in the dry season.

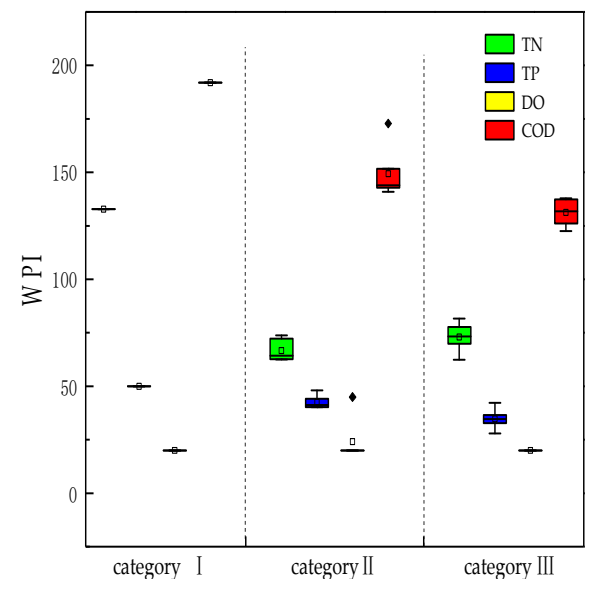

Figure 9. Box and whisker plots of spatial variation in the dry season.

Figure 10 shows the spatial variation in WPI in January and in April (the dry season). Category I, category II, and category III were defined as the highly polluted regions near the lake inlet, the moderately polluted regions located in the centre of lake, and the less polluted regions close to the outlet, respectively. In January, the WPI followed the order: $\mathrm{WPI}_{\mathrm{COD}}>\mathrm{WPI}_{\mathrm{TN}}>\mathrm{WPI}_{\mathrm{TP}}=\mathrm{WPI}_{\mathrm{DO}}$, and the $\mathrm{WPI}_{\mathrm{COD}}$ and $\mathrm{WPI}_{\mathrm{TN}}$ were much higher in category I, with values of 241 and 181, respectively, than in categories II and III, which had mean WPI $\mathrm{COD}_{\mathrm{CO}}$ and $\mathrm{WPI}_{\mathrm{TN}}$ values of 142 and 82, respectively. The $\mathrm{WPI}_{\mathrm{TP}}$ and WPI $\mathrm{DO}_{\mathrm{D}}$ had the same value of 20 in all three categories. In April, the WPI in categories I and II followed the order of WPI $\mathrm{WOD}_{\mathrm{C}}>\mathrm{WPI}_{\mathrm{TP}}>\mathrm{WPI}_{\mathrm{TN}}>\mathrm{WPI}_{\mathrm{DO}}$, while in category III, WPI $\mathrm{IOD}_{\mathrm{CO}}>\mathrm{WPI}_{\mathrm{TN}}$ $>\mathrm{WPI}_{\mathrm{TP}}>\mathrm{WPI}_{\mathrm{DO}}$ in most of the sampling sites. The mean value of $\mathrm{WPI}_{\mathrm{COD}}$ was 142 in category I and category II, which was higher than that in category III (120). 


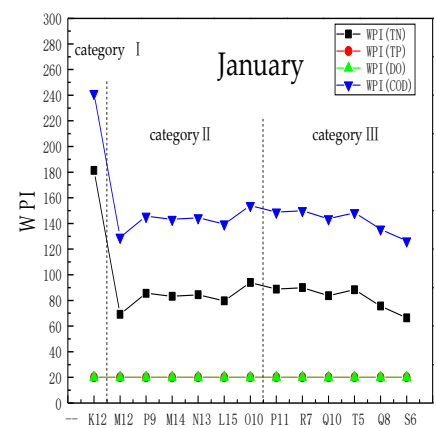

(a)

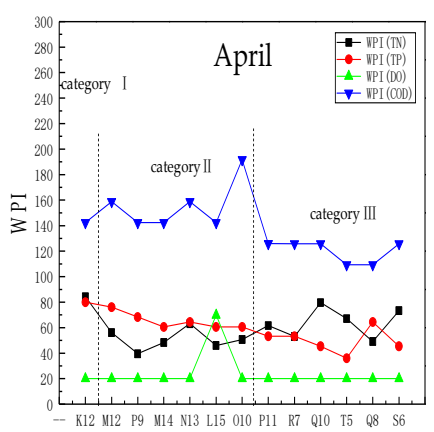

(b)

Figure 10. Spatial variation in WPI in 13 sampling sites in the dry season: (a) January; (b) April.

The cluster analysis of 13 water quality sampling sites in the wet season (Figure 11) also divided them into three regions. The box and whisker plots of spatial variation are shown in Figure 12. Category III, defined as the highly polluted region, consisted of R7, T5, and S6. Category I, the moderately polluted regions, consisted of K12, N13, P11, and M12. Category II, the less polluted regions, consisted of L15, Q8, M14, O10, P9 and Q10 in the centre regions.

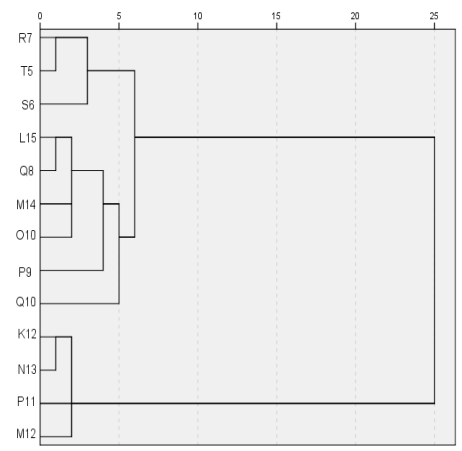

Figure 11. Cluster analysis of sampling sites in the wet season.

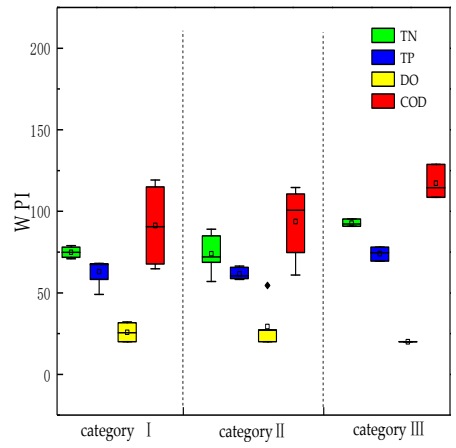

Figure 12. Box and whisker plots of spatial variation in the wet season.

The spatial variation in the WPI is shown in Figure 13. In the wet season, category III was defined as the highly polluted area close to the lake outlet, the moderately polluted region near the lake inlet and the less polluted area near the lake centre. In June, the WPI in categories II and III followed the order $\mathrm{WPI}_{\mathrm{COD}}>\mathrm{WPI}_{\mathrm{TN}}>\mathrm{WPI}_{\mathrm{TP}}>\mathrm{WPI}_{\mathrm{DO}}$, and the mean WPI value was 50 in category $\mathrm{I}_{\text {, lower than }}$ that in category III. In July, the WPI of category III followed the order: $\mathrm{WPI}_{\mathrm{COD}}>\mathrm{WPI}_{\mathrm{TN}}>\mathrm{WPI}_{\mathrm{TP}}>$ $\mathrm{WPI}_{\mathrm{DO}}$, and the average WPI value was 89 in category III, which was higher than in categories I and II. In August, the variation in TN, TP, COD and DO had no apparent order. In October, categories II and III followed the order $\mathrm{WPI}_{\mathrm{COD}}>\mathrm{WPI}_{\mathrm{TN}}>\mathrm{WPI}_{\mathrm{TP}}>\mathrm{WPI}_{\mathrm{DO}}$, and the mean $\mathrm{WPI}_{\mathrm{COD}}$ value of the 13 sampling sites was 96. 


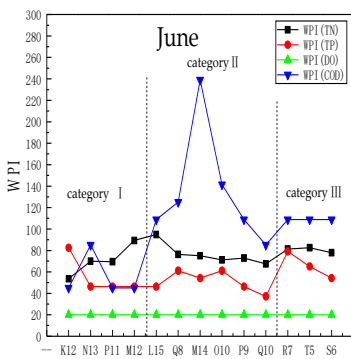

(a)

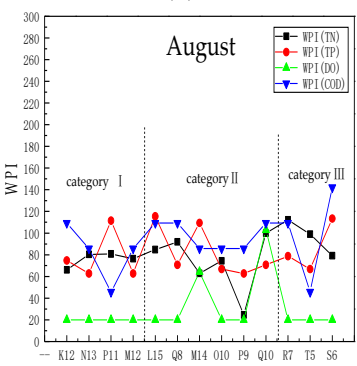

(c)

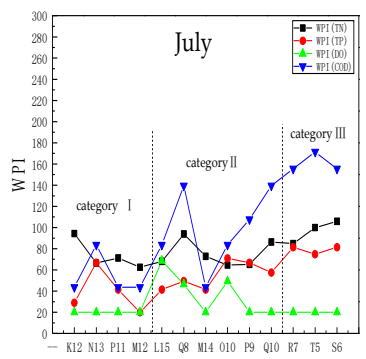

(b)

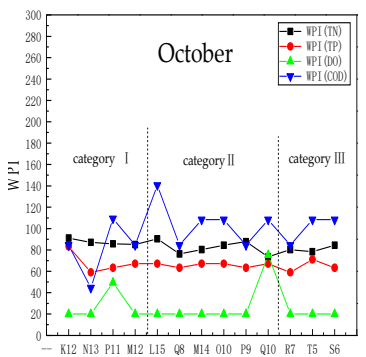

(d)

Figure 13. Spatial variation in the WPI in each sampling site in the wet season: (a) June; (b) July; (c) August; (d) October.

Table 4 shows the results of the Daniel trend test for the spatial variation in the sampling sites in Lake Ulansuhai. The $\mathrm{WPI}_{\mathrm{TN}}$ decreased from the inlet to the outlet region in October but increased in July and August. The $\mathrm{WPI}_{\mathrm{TP}}$ increased from the inlet to the outlet region in January, July, and August, but decreased in April. The $\mathrm{WPI}_{\mathrm{COD}}$ increased from the inlet to the outlet region in June and July but decreased in April. The $\mathrm{WPI}_{\mathrm{DO}}$ increased from the inlet to the outlet region in June and August. For other conditions, the variations did not yield an Rs value greater than Wp, so they were not considered significant.

Table 4. Spatial variation in the WPI values calculated by the Daniel trend method in six sampling months.

\begin{tabular}{|c|c|c|c|c|}
\hline Sampling Period & $\mathbf{N}$ & Water Indicator & $W_{p^{a}}$ & Rs \\
\hline \multirow[t]{4}{*}{ January } & 13 & $\mathrm{TN}$ & $0.456-0.506^{\mathrm{b}}$ & -0.115 \\
\hline & 13 & $\mathrm{TP}$ & $0.456-0.506^{\mathrm{b}}$ & 0.572 \\
\hline & 13 & $\mathrm{COD}_{\mathrm{cr}}$ & $0.456-0.506^{\mathrm{b}}$ & 0.428 \\
\hline & 13 & $\mathrm{DO}$ & $0.456-0.506^{\mathrm{b}}$ & 0.281 \\
\hline \multirow[t]{4}{*}{ April } & 13 & $\mathrm{TN}$ & $0.456-0.506^{\mathrm{b}}$ & 0.179 \\
\hline & 13 & $\mathrm{TP}$ & $0.456-0.506^{\mathrm{b}}$ & -0.664 \\
\hline & 13 & $\mathrm{COD}_{\mathrm{cr}}$ & $0.456-0.506^{\mathrm{b}}$ & -0.648 \\
\hline & 13 & DO & $0.456-0.506^{\mathrm{b}}$ & 0.231 \\
\hline \multirow[t]{4}{*}{ June } & 13 & $\mathrm{TN}$ & $0.456-0.506^{\mathrm{b}}$ & 0.176 \\
\hline & 13 & $\mathrm{TP}$ & $0.456-0.506^{\mathrm{b}}$ & 0.231 \\
\hline & 13 & $\mathrm{COD}_{\mathrm{cr}}$ & $0.456-0.506^{\mathrm{b}}$ & 0.910 \\
\hline & 13 & DO & $0.456-0.506^{\mathrm{b}}$ & 0.737 \\
\hline \multirow[t]{4}{*}{ July } & 13 & $\mathrm{TN}$ & $0.456-0.506^{\mathrm{b}}$ & 0.517 \\
\hline & 13 & $\mathrm{TP}$ & $0.456-0.506^{\mathrm{b}}$ & 0.825 \\
\hline & 13 & $\mathrm{COD}_{\mathrm{cr}}$ & $0.456-0.506^{\mathrm{b}}$ & 0.94 \\
\hline & 13 & $\mathrm{DO}$ & $0.456-0.506^{\mathrm{b}}$ & -0.115 \\
\hline \multirow[t]{4}{*}{ August } & 13 & $\mathrm{TN}$ & $0.456-0.506^{\mathrm{b}}$ & 0.528 \\
\hline & 13 & $\mathrm{TP}$ & $0.456-0.506^{b}$ & 0.039 \\
\hline & 13 & $\mathrm{COD}_{\mathrm{cr}}$ & $0.456-0.506^{\mathrm{b}}$ & 0.286 \\
\hline & 13 & $\mathrm{DO}$ & $0.456-0.506^{\mathrm{b}}$ & 0.605 \\
\hline \multirow[t]{4}{*}{ October } & 13 & $\mathrm{TN}$ & $0.456-0.506^{b}$ & -0.670 \\
\hline & 13 & $\mathrm{TP}$ & $0.456-0.506^{\mathrm{b}}$ & -0.307 \\
\hline & 13 & $\mathrm{COD}_{\mathrm{cr}}$ & $0.456-0.506^{\mathrm{b}}$ & 0.385 \\
\hline & 13 & $\mathrm{DO}$ & $0.456-0.506^{\mathrm{b}}$ & 0.099 \\
\hline
\end{tabular}

( ${ }^{a}$ Rs is the significance level of unilateral test, where $<0.05$ indicates significance when $\mathrm{N}=12, \mathrm{~W} p=0.506$; when $\mathrm{N}=14, \mathrm{Wp}=0.456$ ). 


\section{Discussion}

\subsection{The Reasons for the Spatio-Temporal Variation in 1998-2017}

\subsubsection{The Reasons for the Temporal Variation in the WPI}

In 1998-2000, $\mathrm{WPI}_{\mathrm{TN}}$ fluctuated by approximately 100 and the $\mathrm{WPI}_{\mathrm{TP}}$ dropped from 120 to 80, which indicated that the water quality was acceptable, and the human activities had less impact on Lake Ulansuhai. From 2001 to 2017, the $\mathrm{WPI}_{\mathrm{TN}}$ and $\mathrm{WPI}_{\mathrm{TP}}$ presented a decreasing trend; however, the maxima of $\mathrm{WPI}_{\mathrm{TN}}$ and $\mathrm{WPI}_{\mathrm{TP}}$ appeared in 2006 and 2001, respectively. Li et al. used the accelerated genetic algorithm and the logistic curve to establish a comprehensive evaluation model to evaluate the characteristics and factors that influenced eutrophication from 1996 to 2003 . The results showed that the eutrophication status of Ulansuhai became worse and was close to level 5-heavy eutrophication. The concentrations of TN and TP were both high, and the water environment deteriorated [34].

The main reasons for the increases in the $\mathrm{WPI}_{\mathrm{TP}}$ and $\mathrm{WPI}_{\mathrm{TN}}$ were as follows: (1) The existing agricultural irrigated area and pasture forests in Hetao Irrigation District had 8.61 million acres, of which farmland area accounted for 7.87 million acres. Related research showed that the consumption of chemical fertilizers was only $7 \times 10^{4} \mathrm{t}$ in 1978 but exceeded $52 \times 10^{4} \mathrm{t}$ in 2002 . Moreover, $70 \%$ of chemical fertilizers applied were not utilized but were directly discharged into the Lake Ulansuhai [35]. Due to excessive fertilizer application by farmers, nitrogen and phosphorus accumulated in the soil were discharged into the Ulansuhai with the return of farmland. (2) According to the Bavannao Water Resources Bulletin, Linhe District had the largest discharge of domestic sewage in the counties around Ulansuhai; the total discharge of urban domestic wastewater reached 151.34 million t/a in Linhe District in 2013. Detergent is one example of a household product found in large amounts in the domestic wastewater that was discharged into Lake Ulansuhai. (3) Internal pollution was another reason for the increase of the $\mathrm{WPI}_{\mathrm{TP}}$ and $\mathrm{WPI}_{\mathrm{TN}}$. Studies have shown that the release of nutrients from sediments can be affected by many factors, such as water temperature, $\mathrm{pH}$, hydraulic disturbances, and biological factors. Sondergaard investigated Arreso Lake in Denmark and found that dynamic suspension can increase the concentrations of nutrients [36]. According to the comprehensive management plan of Ulansuhai, TN varies from 0.73 to $3.47 \mathrm{~g} / \mathrm{kg}$ and TP ranges from 0.18 to $1.21 \mathrm{~g} / \mathrm{kg}$ in the surface sediment. The $\mathrm{WPI}_{\mathrm{TN}}$ is much higher than the $\mathrm{WPI}_{\mathrm{TP}}$, indicating that the pollution from nitrogen sources in Ulansuhai is more serious. (4) A number of sewage treatment plants, water reuse projects, and reclaimed water supply projects were set up to control point source pollution in the upstream county in 2008 .

The decreases in the $\mathrm{WPI}_{\mathrm{TN}}$ and $\mathrm{WPI}_{\mathrm{TP}}$ in 2003 occurred because the water conservancy department of Bayannao transported the irrigation gap water in the ice flood season and non-irrigation period from the Yellow River to the Lake Ulansuhai for ecological water compensation. Even with the water transport in 2003, the $\mathrm{WPI}_{\mathrm{TN}}$ reached its maximum in 2006. The peak in the $\mathrm{WPI}_{\mathrm{TN}}$ can be explained by the serious water contamination accident in the Hetao irrigation area in 2005. This contamination event not only deteriorated the water quality in the Hetao irrigation region, but also led to an accumulation of pollutants in Lake Ulansuhai. Moreover, ecological water compensation was relatively less impactful, and the $\mathrm{WPI}_{\mathrm{TN}}$ increased in 2005 and was maximized in 2006.

The increases in the $f \mathrm{WPI}_{\mathrm{COD}}$ was related to the discharge of wastewater containing organic matter from industries such as fertilizer, paper, food processing and manufacturing, metal smelting, and livestock and poultry slaughter. COD reflects the level of pollution by reducing substances in water and is used as a comprehensive indicator of organic pollution. The reducing substances mainly include organics, nitrites, nitrates, sulfides, and ferrous salt. Zhou et al. have shown that the total COD emission increased from 10.2 to $12.3 \mathrm{t}$ year by year since 2005 in the Hetao Irrigation District [37]. To control the aggravating pollution, the government took some actions including comprehensive remediation, closing factories with serious pollution, and treating 73 pollutants in sewage treatment facilities. In 2007, the wastewater reached the standard for discharge, and the water quality began to improve. In 
2008, the Bayannao Water Resources Bulletin showed that the major pollutants of Ulansuhai were organic substances, with rates of COD, TN, and TP of 50\%, 33.3\%, and 16.7\%, respectively. In recent years, water pollution incidents involving large-scale Huangtai outbreaks have appeared continuously in Ulansuhai. WPI $\mathrm{COD}$ increased again and the water quality deteriorated, which resulted from tourism and aquaculture pollution.

The WPI $\mathrm{DO}_{\mathrm{DO}}$ was higher from 2002 to 2010, and the variation in DO was related to the spatial distribution of aquatic plants and their physiological and biochemical characteristics.

In sum, the regime shifts in water quality in Lake Ulansuhai mainly occurred in 2004, 2007, and 2013, and the reasons were as follows: (1) Since 2003, $11.67 \times 10^{7} \mathrm{~m}^{3}$ of ecological compensation water was directly discharged into Lake Ulansuhai, and the water quality improved significantly. (2) Since 2007, the utilization rate of agricultural fertilizers has reduced from $63 \mathrm{~kg}$ per mu to 55 $\mathrm{kg}$ per mu by adjusting the industrial structure and developing soil testing formula fertilization in agriculture. To control the non-point source pollution, the government promoted the efficient use of chemical fertilizers, which resulted in the application of less poisonous pesticides, green prevention, and control technologies for crop pests and diseases. (3) Since 2013, the annual average ecological water compensation has increased to $2 \sim 3 \times 10^{9} \mathrm{~m}^{3}$. The government strengthened the management and proposed comprehensive measures to improve the water quality in Lake Ulansuhai. In summary, the regime shifts of water quality in Lake Ulansuhai occurred due to strengthened governmental management and proposed comprehensive measures.

Linear regression analyses were conducted using the WPI and ecological water compensation, where a significant correlation $(\mathrm{P}<0.01)$ was established. Significant negative correlations $(\mathrm{P}<0.01)$ were found between the WPI values of $\mathrm{TN}, \mathrm{TP}, \mathrm{DO}$, and $\mathrm{COD}\left(\mathrm{WPI}_{\mathrm{TN}}, \mathrm{WPI}_{\mathrm{TP}}, \mathrm{WPI}_{\mathrm{DO}}\right.$, and $\left.\mathrm{WPI}_{\mathrm{COD}}\right)$ and ecological water compensation. After continuous ecological water compensation, the water quality of Ulansuhai improved significantly. Figure 14 shows the ecological water compensation of Ulansuhai from 2003 to 2017. Annual precipitation, mean temperature, and maximum wind speed did not have relationships with the WPI values of $\mathrm{TN}, \mathrm{TP}, \mathrm{DO}$, and COD.

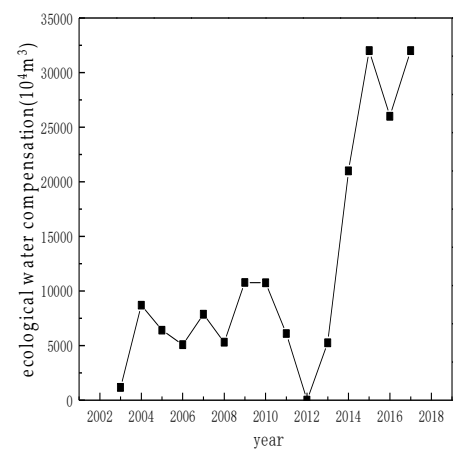

Figure 14. The ecological water compensation in Ulansuhai from 2003 to 2017.

\subsubsection{The Reasons for Spatial Variation in the WPI in 2017}

The concentrations of nitrogen and phosphorus nutrients were much higher in the lake inlet than in the lake centre and lake outlet. The concentrations of TN and TP exceeded the Class V limit upper risk rates by $96.4 \%$ and $96.2 \%$, respectively [38]. The main reason for this was that Lake Ulansuhai, a drainage area of the Hetao Irrigation District, received large amounts of nitrogen and phosphorus from farmland irrigation return water. The $\mathrm{WPI}_{\mathrm{DO}}$ was low in the lake inlet, due to a dense population of photosynthetic aquatic plants in the north lake inlet and high exposure to atmospheric aeration [39]. This is consistent with the results from Ren, which showed that the WPI $I_{D O}$ was high in the lake inlet due to the discharge of industrial wastewater and domestic sewage in the upstream Linhe District and Wuyuan County in 1998-2007, which caused the decomposition of a large amount of organic

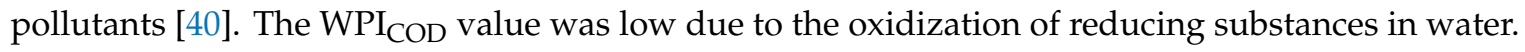


With the migration of nutrients in the lake, some of the nitrogen and phosphorus were removed by biodegradation and sedimentation, which led to significantly lower concentrations of TN and TP in the lake centre than in the lake inlet. The oxygen consumption was reduced due to the decomposition of organic pollutants by microorganisms, and the concentration of DO increased as photosynthetic algae released oxygen [41]. The $\mathrm{WPI}_{\mathrm{DO}}$ was lower in the lake centre and outlet than in the lake inlet. Due to the absorption of aquatic plants and the degradation of organic pollutants, the concentration of COD decreased and the WPI $\mathrm{COD}_{\mathrm{C}}$ was lower in the lake centre than in the lake inlet.

In the lake outlet, the concentrations of $\mathrm{TN}$ and $\mathrm{TP}$ were diluted and the $\mathrm{WPI}_{\mathrm{TN}}$ and $\mathrm{WPI}_{\mathrm{TP}}$ also decreased, which was consistent with the finding of Guo et al. [42]. The sources of nitrogen and phosphorus discharge into the lake included the farmland irrigation return water, groundwater, flooding, irrigation return water, and precipitation. The average nutrient input to the Ulansuhai was approximately $75.5 \times 10^{4} \mathrm{t} / \mathrm{a}$, and TN and TP in the lake inlet were approximately 1088.59 and $65.75 \mathrm{t}$, respectively. The removal pathways of nitrogen and phosphorus included discharge into the Yellow River, harvest reeds, fish, and feed birds. The average outputs of TN and TP were approximately 759.9 and $37.8 \mathrm{t}$, respectively [35]. The WPI $\mathrm{COD}$ was generally higher in the lake outlet, which was related to point source pollution, such as sewage treatment plant tail water.

Among the four typical indicators, the WPI $\mathrm{TN}_{\mathrm{TN}}$ is the largest, followed by WPI $\mathrm{COD}$ and $\mathrm{WPI}_{\mathrm{TP}}$. Therefore, reducing nitrogen was critical to improve the water quality of the Ulansuhai. WPI $\mathrm{DO}_{\mathrm{DO}}$ ranged from 20 and 80 in Ulansuhai in 1998 and 2017, much lower than the WPI $\mathrm{TN}_{\mathrm{TN}}, \mathrm{WPI}_{\mathrm{TP}}$, and WPI $\mathrm{I}_{\mathrm{COD}}$; however, $\mathrm{WPI}_{\mathrm{COD}}$ was not the main water pollution indicator.

\subsection{The Reasons for Temporal and Spatial Variations in 2017}

\subsubsection{The Reasons for the Temporal Variations in the WPI in 2017}

The temporal variation was grouped into the dry season and wet season, and the reasons for WPI variations were different. The WPI $\mathrm{COD}_{\mathrm{D}}$ was much higher than $\mathrm{WPI}_{\mathrm{TN}}, \mathrm{WPI}_{\mathrm{TP}}$, and $\mathrm{WPI}_{\mathrm{DO}}$ both in the dry season and in the wet season, and COD was the main pollution indicator in Lake Ulansuhai. High COD results in the death of aquatic organisms due to a lack of oxygen and a bad water odour. The sources of COD are complex and diverse. COD originates from not only exogenous sources (non-point and sewage treatment plant tail water) but also from endogenous releases (sediment release and algae release). COD has different conversion and accumulation processes due to its different structural characteristics [43]. With the expanding scale of fish farming, aquaculture activities that are suitable for semi-enclosed areas with slow water flow will lead to the accumulation of remaining baits and wastes and will result in different levels of organic pollution. Furthermore, sewage treatment plant tail water is another source of deteriorating water quality. The WPI $\mathrm{COD}_{\mathrm{C}}$ had the highest value in 2017. The comprehensive management plan of Ulansuhai showed that, in 2013, COD, TN, and TP in the lake inlet reached 22,471, 2402, and $243 \mathrm{t} / \mathrm{a}$, respectively. Similarly, increased COD was also found in the North-eastern United States, indicating that the increased dissolved organic matter (DOM) in lakes was primarily derived from litter and soil [44]. In 2007, the WPI $\mathrm{C}_{\mathrm{COD}}$ was higher than the WPI $\mathrm{I}_{\mathrm{TN}}$, $\mathrm{WPI}_{\mathrm{TP}}$, and WPI $\mathrm{DO}$.

In most of the sampling sites, the WPI $\mathrm{IOD}_{\mathrm{C}}$ values were higher in the dry season than in the wet season. In the dry season, January was the freezing period, where the water exchange capacity was poor and the accumulation of pollutants caused internal pollution. With the rise of the temperature in April, the ice body melted, and the internal pollution was released. Due to water replenishment mainly from industrial wastewater and domestic sewage, the water self-purification ability was poor. The rising temperatures in June, July, August, and October were more beneficial to microbial activities and the decomposition efficiency of organic pollutants, which resulted in a decrease in the WPI $\mathrm{COD}_{\mathrm{D}}$ in the wet season. Another reason for this effect was that precipitation was scarce in the dry season but significantly increased in the wet season, causing a pollution dilution effect (Figure 15). 


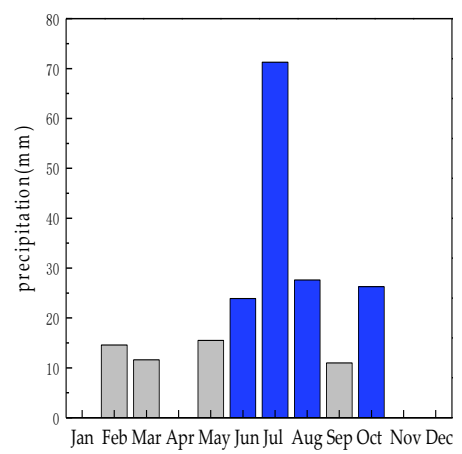

Figure 15. Urad front banner monthly precipitation in 2017.

The WPI $\mathrm{TN}_{\mathrm{TN}}, \mathrm{WPI}_{\mathrm{TP}}$, and $\mathrm{WPI}_{\mathrm{DO}}$ were higher in the wet season than in the dry season in 2017. This conclusion opposes the findings of Wang et al., who reported that the WPI value was higher in the dry season than in the wet season on the north bank of Lake Dianchi. Wang et al. also reported that the storm rain scouring effect contributed to the dilution of pollutants, which contributes to the difference in results found by the two studies [12]. The main reason for the difference in results stems from the different sources of compensation water in the two lakes. Lake Ulansuhai is located in the arid and semiarid regions of the northern middle temperate region, so when farmers began to fertilize and irrigate heavily in the Hetao Irrigation District in the spring and summer, a large amount of nitrogen and phosphorus were discharged into Ulansuhai. Furthermore, due to the hydraulic erosion caused by rainfall, pollutants from farmland soil were carried into the lake through runoff and sediment, which was the main reason why $\mathrm{WPI}_{\mathrm{TN}}$ and $\mathrm{WPI}_{\mathrm{TP}}$ were higher in the wet season. In addition, an increase in tourism in Ulansuhai from June to October resulted in an increase in pollution.

\subsubsection{The Reasons for the Spatial Variations in WPI in 2017}

Ulansuhai is the only drainage channel for farmland irrigation return water, industrial wastewater, and domestic sewage in the Hetao Irrigation District, with drainage ratios of $96 \%, 2 \%$, and $2 \%$, respectively [26]. Table 5 shows the comparison of the spatial variation in the sampling sites in the dry season and in the wet reason. In the dry season, K12 was classified as a highly polluted area because it was close to the lake inlet, and additionally, a large amount of farmland returned water was discharged into the lake and concentrated at this site. P9, M14, L15, and O10, which were located in the lake centre and near the reed area, were classified as the moderately polluted areas. The main reason for this classification was that large aquatic plants purified the pollutants in the water and improved the water quality. T5, S6, R7, and P11 were classified as the less polluted areas because human activity was not frequent, and with dilution and purification, the water quality become better. However, in the wet season, the T5, S6, and R7 sites changed from less polluted areas to highly polluted areas. The main explanation for the increase in pollution from May to October was the close proximity of the three sites to the fishery farming area, where a large amount of fishing baits and excreta directly entered the lake ecological cycle. The fish farms expanded from May to October, and the increases in nitrogen, phosphorus, and organic pollutants caused serious water pollution. Studies from Xu et al. showed that only $13.9 \%$ of the nitrogen and $25.4 \%$ of the phosphorus in the bait entered into fishery products. The rest was deposited in the sediment [45], which would be released in the wet season. K12 changed from a highly polluted area in the dry season to a moderately polluted area in the wet season. The main explanation for the change in $\mathrm{K} 12$ during the dry season resulted from the thawing of the frozen period (January-April), releasing sources of domestic sewage and industrial effluence, with little contribution from farmland irrigation return water. K12 was near the lake inlet, and internal pollution caused the water quality to deteriorate compared with the wet season. The P9, M14, L15, and O10 sites changed from moderately polluted areas in the dry season to less polluted areas in the wet season. The main reason for this change was that these sampling sites were near the lake centre, where there was high precipitation, and the dilution effect improved the water quality in the wet season. In addition, the 
pollution levels of M12, N13, Q8, and Q10 had no changes in either the wet season or the dry season of 2017. M12 and N13 were classified as moderately polluted areas, while Q8 and Q10 were classified as less polluted areas.

Table 5. Partition of sampling sites in the dry season and wet season.

\begin{tabular}{ccc}
\hline & The Dry Season & The Wet Season \\
\hline Highly polluted areas & K12 & T5, S6, R7 \\
Moderately polluted areas & M12, N13, P9, M14, L15, O10 & M12, N13, P11, K12 \\
Less polluted areas & Q8, Q10, P11, T5, S6, R7 & Q8, Q10, P9, M14, L15, O10 \\
\hline
\end{tabular}

\section{Conclusions}

In this study, the WPI method was used to assess the temporal and spatial variation in the water quality for a period of time in Lake Ulansuhai. We think that the WPI proved to be a suitable method of water quality in the eutrophic shallow lake. In this region, the water quality was mainly affected by organic pollutants from non-point agricultural sources. In 1998-2017, TN was the major pollution indicator, followed by COD and TP, and in 2017, COD was the dominant factor influencing water quality. The WPI $\mathrm{COD}_{\mathrm{C}}$ value in the dry season was significantly higher than the $\mathrm{WPI}_{\mathrm{TN}}, \mathrm{WPI}_{\mathrm{TP}}$ and $\mathrm{WPI}_{\mathrm{DO}}$, while the $\mathrm{WPI}_{\mathrm{TN}}, \mathrm{WPI}_{\mathrm{TP}}$ and $\mathrm{WPI}_{\mathrm{DO}}$ were higher than the $\mathrm{WPI}_{\mathrm{COD}}$ in the wet season. The main reasons were as follows: (1) non-point source pollution and fish farming activities, (2) point source pollution such as industrial wastewater and domestic sewage, (3) internal pollution released from the sediment, and (4) ecological water compensation from the Yellow River. Based on the above results, the water quality should control or ration the consumption of fertilizers and pesticides. These results provide a reference and present suggestions for the improvement and effective management of lake water quality. In future work, we will explore the impact of reducing irrigation and ecological water compensation by optimizing water allocation and improving the lake water quality.

Author Contributions: Q.Z. and R.Y. designed the research framework and wrote the manuscript. R.Y. supervised the study. L.W. and Y.H. collected Inner Mongolia environmental monitoring station data. Q.Z., Y.J., H.X. and X.L. carried out the field experiments and laboratory experiments analyses. Z.Z. drew GIS mapping in this paper. X.L. proofread the manuscript.

Funding: This study was funded by the National Natural Science Foundation of China (grant numbers 51869014, 51469018, 61461034), Science and Technology Major Project on Lakes of Inner Mongolia (No.ZDZX2018054), and the National Key Research and Development Program of China (Grant No.2016YFC0500508).

Acknowledgments: We thank X. X. Lu for their expertise and technical reviews of this manuscript.

Conflicts of Interest: The authors declare no conflict of interest.

\section{References}

1. Yang, G.S.; Ma, R.H.; Zhang, L.; Jiang, J.H.; Yao, S.C.; Zhang, M.; Zeng, H.A. Lake status major problems and protection strategy in China. J. Lake Sci. 2010, 22, 799-810. [CrossRef]

2. Garizi, A.Z.; Sheikh, V.; Sadoddin, A. Assessment of seasonal variations of chemical characteristics in surface water using multivariate statistical methods. Int. J. Environ. Sci. Technol. 2011, 8, 581-592. [CrossRef]

3. Liu, R.; Chen, Y.; Yu, W.; Xu, F.; Shen, Z.Y. Spatial-temporal distribution and fuzzy comprehensive evaluation of total phosphorus and total nitrogen in the Yangtze River Estuary. Water Sci. Technol. 2016, 73, 924-934. [CrossRef] [PubMed]

4. Ip, W.C.; Hu, B.Q.; Wong, H.; Xia, J. Applications of grey relational method to river environment quality evaluation in China. J. Hydrol. 2009, 379, 284-290. [CrossRef]

5. Alves, D.D.; Riegel, R.P.; De, D.Q.; Osório, D.M.M.; Da, G.C.; Do, C.N.; Telöken, F. Seasonal assessment and apportionment of surface water pollution using multivariate statistical methods: Sinos River, southern Brazil. Environ. Monit. Assess. 2018, 190, 384. [CrossRef] [PubMed] 
6. Ahamad, K.U.; Raj, P.; Barbhuiya, N.H.; Deep, A. Surface Water Quality Modeling by Regression Analysis and Artificial Neural Network. In Advances in Waste Management; Springer: Singapore, 2019; pp. 215-230. Available online: https://link.springer.com/chapter/10.1007/978-981-13-0215-2_15. (accessed on 8 July 2019). [CrossRef]

7. Tang, T.; Zhai, Y.; Huang, K. Water Quality Analysis and Recommendations through Comprehensive Pollution Index Method. Manag. Sci. Eng. 2011, 5, 95-100.

8. Zhang, Y.L.; Zhou, Y.; Cheng, Z.; Yao, Z.P.; Shen, J.; Wang, X.L. Comparison and analysis of different evaluation methods for water quality in the Danjiangkou valley. Environ. Monit. China 2015, 31, 58-61. [CrossRef]

9. Liu, Y.; Zheng, B.H.; Fu, Q.; Luo, Y.P.; Wang, M. Application of water pollution index in water quality assessment of rivers. Environ. Monit. China 2013, 29, 49-55. [CrossRef]

10. Ma, Y. Application of water pollution index in water quality assessment of rivers. Tech. Superv. Water Resour. 2017, 25, 11-12. [CrossRef]

11. Popovic, N.Z.; Duknic, J.A.; Atlagic, J.Z.C.; Raković, M.J.; Marinković, N.S.; Tubić, B.P.; Paunović, M.M. Application of the water pollution index in the assessment of the ecological status of rivers: A case study of the Sava River, Serbia. Acta Zool. Bulg. 2016, 68, 97-102.

12. Wang, Q.; Li, Y.X.; He, J.; Xu, X.M.; Wu, X.H. Analysis of water quality variation trend in lake inlet river on north of lake Dianchi. Environ. Sci. Technol. 2012, 35, 191-194. [CrossRef]

13. Wang, Q.; Wu, X.H.; Zhao, B.; Qin, J.; Peng, T.C. Combined Multivariate Statistical Techniques, Water Pollution Index (WPI) and Daniel Trend Test Methods to Evaluate Temporal and Spatial Variations and Trends of Water Quality at Shanchong River in the Northwest Basin of Lake Fuxian, China. PLoS ONE 2015, 10, e0118590. [CrossRef] [PubMed]

14. Liu, H.; Wu, J.J. Application of water pollution index in water quality assessment of rivers. J. Anhui Agric. Sci. 2014, 21, 7164-7165. [CrossRef]

15. Li, R.; Zou, Z.; Yan, A. Water quality assessment in Qu River based on fuzzy water pollution index method. J. Acta Sci. Circumstantiae 2016, 50, 87-92. [CrossRef] [PubMed]

16. Milanović, A.; Milijašević, D.; Brankov, J. Assessment of polluting effects and surface water quality using water pollution index: A case study of hydro-system Danube-Tisa-Danube, Serbia. Carpathian J. Earth Environ. Sci. 2011, 6, 269-277.

17. Brankov, J.; Evi, D.M.; Milanovi, A. The Assessment of the Surface Water Quality Using the Water Pollution Index: A Case Study of the Timok River (The Danube River Basin), Serbia. J. Arch. Environ. Prot. 2012, 38, 49-61. [CrossRef]

18. Nikolaidis, C.; Mandalos, P.; Vantarakis, A. Impact of intensive agricultural practices on drinking water quality in the Evros region (NE Greece) by GIS analysis. Environ. Monit. Assess. 2008, 143, 43-50. [CrossRef]

19. Burton, L.R.; Howard, A.; Goodall, B. Construction of a historical Water Pollution Index for the Mersey Basin. Area 2003, 35, 438-448. [CrossRef]

20. Zhao, S.N.; Li, C.Y.; Shi, X.H.; Zhang, H.M.; Wang, S. Bioavailability and environment pollution evaluation of sediments heavy metals in Wuliangsuhai lake. Ecol. Environ. Sci. 2013, 22, 481-489. [CrossRef]

21. Wang, X.W.; Yang, H.; Cai, Y.P.; Yu, C.X.; Yue, W.C. Identification of optimal strategies for agricultural nonpoint source management in Ulansuhai Nur watershed of Inner Mongolia, China. Stoch. Environ. Res. Risk Assess. 2016, 30, 137-153. [CrossRef]

22. Mao, X.F.; Wei, X.Y.; Yuan, D.H.; Jin, Y.X.; Jin, X. An ecological-network-analysis based perspective on the biological control of algal booms in Ulansuhai Lake, China. Ecol. Model. 2018, 386, 11-19. [CrossRef]

23. Lv, J.; Li, C.Y.; Zhao, S.N.; Sun, B.; Shi, X.H.; Tian, W.D. Evaluation of nutritional status in Wuliangsuhai in frozen and non-frozen seasons. Arid Land Resour. Environ. 2018, 32, 109-114. [CrossRef]

24. Jiang, H.Q.; Li, C.Y.; Shi, X.H.; Zhang, G.F. Comprehensive evaluation of water quality for Wuliangsuhai lake. J. Water Sav. Irrig. 2010, 5, 15-17.

25. Tian, W.D.; Jia, K.L.; Shi, X.H.; Zhao, S.N.; Wu, Y.; Song, S.; Ma, J. Water quality variation in Lake Wuliangsuhai, 2005-2014. J. Lake Sci. 2016, 28, 1226-1234. [CrossRef]

26. Sun, H.M.; He, J.; Lv, C.W.; Gao, X.D.; Fan, Q.Y.; Xue, H.X. Nitrogen pollution and spatial distribution pattern of Wuliangsuhai lake. Geogr. Res. 2006, 25, 1003-1012. [CrossRef] 
27. Zhang, Y.M.; Jiao, S.W.; Jia, Y.F.; Zeng, Q.; Feng, D.D.; Lei, G.C. Spatial and temporal variations in waterbird communities and its implications for ecosystem management in a large temperate arid wetland of northwest P.R. China. Avian Biol. Res. 2017, 10, 119-128. [CrossRef]

28. The Ministry of Environmental Protection of the People's Republic of China. Environment Quality Standards for Surface Water; GB3838-2002; State Environment Protection Administration of China: Beijing, China, 2002.

29. Gao, W.; Chen, Y.; Xu, M.; Guo, H.C. Trend and driving factors of water quality change in lake Fuxian (1980-2011). J. Lake Sci. 2013, 25, 635-642. [CrossRef]

30. Abudumutailifu, M.; Halik, Ü.; Aishan, T.; Keyimu, M.; Nasirdin, N.; Ainiwaer, A. Variation Characteristics of the main atmospheric pollutant conccentration in Urumqi. Ecol. Environ. Sci. 2018, 27, 533-541. [CrossRef]

31. Lang, Z.Y.; Liu, Y.; Sheng, H. Identification of water quality trends in Lake Dianchi using an integrated STL and RSI approach. Acta Sci. Circumstantiae 2014, 34, 754-762. [CrossRef]

32. Alfred, M.; Powell, J.; Xu, J.J. The 1977 Global Regime Shift: A Discussion of Its Dynamics and Impacts in the Eastern Pacific Ecosystem. Atmos. Ocean 2012, 50, 421-436. [CrossRef]

33. Xu, J.J.; Alfred, M.; Powell, J. Two mechanisms responsible for marine ecosystem regime shifts from fish landings data off the West Coast of California (WCC). Nat. Sci. 2013, 5, 495-500. [CrossRef]

34. Li, C.Y.; Liu, T.X.; Gao, R.Z.; Ren, C.T. Study and synthetic assessment for the season-year change of the eutrophication main-control factors in Wuliangsuhai Lake. Hydrology 2004, 24, 14-17.

35. Shang, S.Y.; Du, J.M.; Li, X.Y.; Shen, Q.T.; Wang, L.M. Ecological restoration engineering technology of eutrophic lake-A case study of Lake Wuliangsuhai in Inner Mongolia. Chin. J. Ecol. 2003, 22, 57-62. [CrossRef]

36. Søndergaard, M.; Kristensen, P.; Jeppesen, E. Phosphorus release from resuspended sediment in the shallow and wind-exposed Lake Arresø, Denmark. Hydrobiologia 1992, 228, 91-99. [CrossRef]

37. Zhou, Y. The Wuliangsuhai Ecological Research Station Building and Health Evaluation Index System; Inner Mongolia University of Science and Technology: Baotou, China, 2012.

38. Li, X.; Gou, M.M.; Wang, Y. Analysis on the exceeding the risk ratio of mouth water quality for Wuliangsuhai lake in Inner Mongolia. J. Agro-Environ. Sci. 2011, 30, 1638-1644. [CrossRef]

39. Astel, A.; Biziuk, M.; Przyjazny, A.; Namies'nik, J. Chemometrics in monitoring spatial and temporal variations in drinking water quality. Water Res. 2006, 40, 1706-1716. [CrossRef] [PubMed]

40. Ren, C.T.; Yang, L.P.; Wei, Z.Z.; Cao, Y.Y. Study on Influence Factors of Dissolved Oxygen Variation in Wuliangsuhai Inlet Water. J. Urban Constr. Theory Res. 2012, 33. Available online: http://d.old.wanfangdata. com.cn/Periodical/csjsllyj2012332944 (accessed on 8 July 2019).

41. Li, W.P. Study on Water Environment Pollution and Hydrological Simulation of Typical Lake; China Water Conservancy and Hydropower Press: Beijing, China, 2015; pp. 84-96.

42. Guo, J.; Wei, W.; Yu, Y.L.; Song, J.X.; Zhang, M.Y.; Li, S.N. Research progress on the eutrophication of Wuliangsuhai wetland. Chin. J. Ecol. 2015, 34, 3244-3252. [CrossRef]

43. Yang, F.; Wang, S.R.; Guo, W.; Ni, Z.K. Specctroscopic analysis and degradation kinetics study of COD in sewage plant effluent into Dianchi Lake. Environ. Eng. Technol. 2017, 7, 558-564. [CrossRef]

44. Sanclements, M.D.; Oelsner, G.P.; Mcknight, D.M.; Stoddard, J.L.; Nelson, S.J. New insights into the source of decadal increases of dissolved organic matter in acid-sensitive lakes of the north eastern united states. Environ. Sci. Technol. 2012, 46, 3212-3219. [CrossRef]

45. Xu, Q. Rice Field Ecosystem in China; China Agriculture Press: Beijing, China, 1998; pp. 154-196.

(C) 2019 by the authors. Licensee MDPI, Basel, Switzerland. This article is an open access article distributed under the terms and conditions of the Creative Commons Attribution (CC BY) license (http://creativecommons.org/licenses/by/4.0/). 